\title{
Jurist-Diction
}

Volume 2 No. 6, November 2019

Histori artikel: Submit 1 Oktober 2019; Diterima 23 Oktober 2019; Diterbitkan online 1 November 2019.

\section{Penghindaran Pajak Pada Potensi Pajak Perjanjian Nominee Dalam Pengalihan Hak Atas Tanah Dan/Atau Bangunan}

\author{
Zulfikar Muhammad Rafif \\ rafifzulfikar@gmail.com \\ Universitas Airlangga
}

\begin{abstract}
There is a lot of foreign agencies and foreigners who want to start a business by investing massively in Indonesia raises a phenomenon where these investors need a gap to overcome the agrarian legal system that adheres to the principle of nationalism. One of the most common ways done by investors is by nominee agreements where the parties are between Foreign Citizens and Indonesian Citizens as the power of attorney (nominee) made through a package of agreements including additional agreements, in essence intended to provide any authority that may arise in the legal relationship between a person and his land to an Indonesian citizen as the proxy for acting as an actual owner in this case is a foreign national from a plot of land and or building. In the additional agreement, there is the potential for tax avoidance through a leasing scheme in the form of income tax on 10\% of land rental and / or building income already settled in Article 4 (1) of the Government Regulation of Republic Indonesia Number 34 year 2017 concerning Income Tax on Income from Rental Land and / or Building. And / or accounts payable in the form of income tax on loan interest of $15 \%$ in accordance with Article 23 paragraph (1) of Law Number 38 Year 2007 concerning the Fourth Amendment to Law Number 7 of 1983 concerning Income Tax. , because the agreement is only limited to minimizing defaults and to be more binding between foreigners as the beneficial owner and Indonesian citizens as nominees.
\end{abstract}

Keywords: Nominee Agreement; Tax Avoidance; Transfer of Land Rights, Income Tax; Foreigner; and Derivative Agreements

\begin{abstract}
Abstrak
Banyaknya badan dan orang asing yang ingin memulai usaha dengan melakukan investasi di Indonesia secara masif menimbulkan suatu fenomena dimana investor tersebut membutuhkan celah untuk mengatasi sistem hukum agrarian yang menganut asas nasionalisme. Salah satu cara yang paling umum dilakukan oleh para investor adalah dengan perjanjan nominee dimana para pihak yakni antara Warga Negara Asing dan Warga Negara Indonesia sebagai pemberi kuasa (nominee) yang dibuat melalui satu paket perjanjian termasuk di dalamnya terdapat perjanjian tambahan, pada hakikatnya bermaksud untuk memberikan segala kewenangan yang mungkin timbul dalam hubungan hukum antara seseorang dengan tanahnya kepada Warga Negara Indonesia selaku penerima kuasa untuk bertindak layaknya seorang pemilik yang sebenarnya dalam hal ini adalah Warga Negara Asing dari sebidang tanah dan atau bangunan. Pada perjanjian tambahan tersebut terdapat potensi penghindaran pajak melalui skema sewa menyewa berupa pajak PPh atas Penghasilan Persewaan Tanah dan/atau Bangungan sebesar 10\% yang sudah tertuai dalam Pasal 4 (1) Peraturan Pemerintah Republik Indonesia Nomor 34 Tahun 2017 tentang Pajak Penghasilan atas Penghasilan Dari Persewaan Tanah dan/atau Bangunan. Dan/atau utang piutang berupa pajak penghasilan atas bunga pinjaman sebesar 15\% sesuai dengan Pasal 23 (1) Undang - Undang Nomor 38 Tahun 2007 tentang Perubahan Ke Empat Atas Undang - Undang Nomor 7 Tahun 1983 tentang Pajak Penghasilan. Dikarenakan perjanjian tersebut hanya sebatas untuk meminimalisir wanprestasi dan untuk lebih mengikat antara WNA selaku beneficial owner dan WNI selaku nominee.
\end{abstract}

Kata Kunci: Perjanjian Nominee; Penghindaran Pajak; Pengalihan Hak Atas Tanah; Pajak Penghasilan; Warga Negara Asing; dan Perjanjian Turunan. 


\section{Pendahuluan}

DiIndonesia sebutan agrarian terdapatpada segmenAdministrasi Pemerintahan dan digunakan dalam artian tanah. ${ }^{1}$ Tanah tersebut diberikan dan dipunyai oleh seseorang yang memiliki hak-hak untuk digunakan dan dimanfaatkan sebagaimana ditentukan dalam Undang - Undang Nomor 5 Tahun 1960 yang dikenal dengan Undang - Undang Pokok Agraria (UUPA). Oleh karena itu berdasarkan Pasal 1 ayat (2) UUPA dinyatakan bahwa hak-hak atas tanah bukan hanya memberikan wewenang mempergunakan sebagian yang ada pada permukaan bumi, tetapi juga bagian bumi yang ada dibawahnya serta ruang yang ada diatasnya.

Orang asing tidak dimungkinkan untuk memiliki tanah berstatus Hak Milik secara yuridis formil, namun adanya praktik yang telah terjadi di beberapa kota di Indonesia selama ini bahwa warga negara asing melakukan pembelian tanah yang berstatus Hak Milik dengan cara mencari seseorang dan meminjam namanya untuk hak milik (nominee arrangement) yang harus berkewarganegaraan negara asal yakni Indonesia dan melahirkan perjanjian utang piutang sebagai perjanjian tambahan yang seakan-akan orang yang dipinjam namanya tersebut berhutang dengan jumlah dan tempo tertentu kepada warga negara asing dengan tujuan dasar menjadikan tanah yang dibeli tersebut sebagai jaminan utangnya.

Pengertian perjanjian tercantum pada Pasal 1313 KUHPerdata adalah "Suatu perbuatan dengan mana satu orang atau lebih mengikatkan dirinya terhadap satu orang lain atau lebih lainnya". Perjanjian adalah sebagai suatu persetujuan dengan mana dua orang atau lebih saling mengikatkan diri untuk melaksanakan suatu hal mengenai harta kekayaan. Perjanjian yang dibuat tersebut dapat berbentuk katakata secara lisan dan dapat pula dalam bentuk tertulis. ${ }^{2}$

Dengan kata lain perjanjian merupakan suatu kejadian dimana salah seorang telah memberikan janji kepada salah seorang yang lain atau dimana para pihak tersebut sepakat untuk melaksanakan suatu. ${ }^{3}$ Perjanjian Nominee atau Nominee

\footnotetext{
${ }^{1}$ Boedi Harsono, Hukum Agraria Indonesia (Djambatan 2003).[5].

2 Abdulkadir Muhammad, Hukum Perjanjian (Citra Aditya Bakti 2000).[4].

3 Subekti, Hukum Perjanjian (Intermasa 2001).[1].
} 
Arrangement merupakan perjanjian khayalan atau perjanjian pura-pura yang dilakukan oleh salah seorang WNI dengan WNA bahwa mereka seolah-olah menunjukkan telah terjadinya perjanjian antara mereka.

Perjanjian Nominee merupakan perjanjian Innominaat karena tidak adanya pengaturan secara khusus dan tidak secara eksplisit dicantumkan dalam pasal-pasal yang ada pada KUH Perdata. Asas kebebasan berkontrak memiliki peran penting sebagai dasar perjanjian nominee karena bentuknya yang innominaat yang berarti tidak ada aturan yang jelas menjelaskan tentang perjanjian nominee tersebut. Objek perjanjian pada perjanjian nominee adalah terkait kepemilikan dimana orang lain mempunyai hal yang ia miliki dan landasan ataupu sertifikat pembuktian kepemilikan tersebut atas nama orang lain atau dengan istilah lain merupakan pinjam nama. Dalam Pasal 1338 KUH Perdata menyebutkan dengan tegas bahwa perjanjian atau perikatan harus sesuai dengan itikad baik dan dilaksanakan karena sebab - sebab tertentu dalam realisasi perjanjian nominee tersebut ternyata justru banyak dipakai untuk melakukan penyelundupan hukum. ${ }^{4}$

Wujud perjanjian nominee ini terletak di dalam isi perjanjian yang disepakati oleh kedua belah pihak, yakni antara orang asing sebagai pemilik manfaat (beneficial owner) dan warga indonesia sebagai yang memberikan kuasa (nominee) yang diciptakan melalui satu pengelompokkan perjanjian itu. Seseorang dengan tanahnya memberikannya kepada beneficial owner dalam hal ini adalah WNA merupakan orang yang menerima kuasa untuk bertindak selayaknya seorang pemilik asli dari luas tanah yang berdasarkan hukum tidak dapat dimiliki. Pada hakekatnya hal tersebut bertujuan untuk secara menyeluruh meleburkan aspek-aspek kewenangan yang akan timbul dalam kaitan hukumnya. Perjanjian yang menekankan pada penggunaan kuasa semacam ini, dengan mengatasnamakan masyarakat Indonesia sebagai nominee merupakan penyelundupan hukum karena isi perjanjiannya sangat tidak sesuai dengan Undang - Undang No. 5 Tahun 1960 atau Undang - Undang Pokok Agraria.

${ }^{4}$ Muhammad Taufiq Budiarto, Sudut Pandang Perpajakan Atas Pengalihan Hak Tanah dan Bangunan dengan Mekanisme Perjanjian Nominee (2018)(Simposium Keuangan Negara).[441]. 
Dalam praktik nominee faktor yang menjadi fokus adalah isi data yang berisi pemilik manfaat dimana salah satu perusahaan dengan bentuk yang sering dipakai untuk oleh para pihak dalam menleburkan informasi pemilik asli (beneficial owner) adalah nominee shareholders. Tidak adanya data yang pasti terkait pemiliki sebenarnya dari usaha tersebut, otoritas perpajakan akan sangat sulit untuk memaksa para pemilik sebenarnya tersebut untuk melimpahkan segala peraturan mengenai investasi termasuk pemungutan pajak yang sudah dibuat dan disahkan oleh negara tersebut. Penghindaran pajak merupakan praktik yang tidak dapat dimaklumi. Selain tergerusnya pemasukan pajak bagi negara, penghindaran pajak pasti mengakibatkan berkurangnya penerimaan pajak oleh negara.

\section{Metode Penelitian}

Pendekatan masalah yang digunakan penulis untuk menjawab rumusan masalah adalah pendekatan undang-undang atau statute approach, pendekatan konseptual atau conceptual approac), dan pendekatan komparatif atau comparative approach. Pendekatan pertama yang akan penulis terapkan adalah pendekatan undang-undang (statute approach) dimana dalam pendekatan ini penulis menelaah undang-undang, peraturan, dan jurisdiksi terkait dengan isu hukum yang penulis ambil.

Pendekatan kedua adalah pendekatan konseptual dimana pendekatan konseptual berawal dari pandangan-pandangan serta doktrin-doktrin yang berkembang dalam ilmu hukum. ${ }^{5}$ Pendekatan ketiga yakni pendekatan komparatif yang dilakukan dengan membandingkan undang-undang suatu negara dengan undang - undang dari satu atau lebih negara lain mengenai hal yang sama. Bertujuan untuk untuk memperoleh persamaan dan perbedaan antara undang-undang tersebut serta untuk menjawab isu mengenai ketentuan undang-undang tersebut. ${ }^{6}$

5 Peter Mahmud Marzuki, Penelitian Hukum Edisi Revisi (Kencanan Prenada Media Group 2011).[135].

6 ibid. 


\section{Praktek Perjanjian Nominee Dalam Pengalihan Hak Atas Tanah Dan/Atau Bangunan Yang Menimbulkan Kerugian Pada Pendapatan Negara}

Penguasaan tanah oleh orang asing dengan melakukan perjanjian nominee secara tidak langsung selain mencederai ketentuan dalam Undang - Undang Agraria, juga merugikan negaran terutama pada fungsi penerimaan pendapatan negara di bidang pajak. Ruang lingkup keuangan negara secara rinci dijelaskan dalam Pasal 2 Undang - Undang Nomor 17 Tahun 2003 tentang Keuangan Negara (UU KN) yang salah satunya meliputi hak negara untuk memungut pajak.

Jimly Asshiddiqie berpendapat bahwa pendapatan dan pengeluaran negara merupakan kegiatan yang dipahami sebagai keuangan negara yang kemudian terafiliasi dalam perumusan ketentuang Undang-Undang Dasar Negara Republik Indonesia Tahun 1945. ${ }^{7}$ M. Ichwan berpendapat bahwa keuangan negara merupakan rencana kegiatan secara kuantitatif yang akan dijalankan untuk masa mendatang yang umumnya untuk 1 (satu) tahun mendatang. ${ }^{8}$ Berdasarkan UU KN, Keuangan negara merupakan seluruh kewajiban dan hak suatu negara yang dapat dinilai secara materiil baik dengan uang, maupun berupa barang yang dapat menjadi milik negara yang berkaitan dengan pelaksanaan kewajiban dan hak tersebut. Sesuai dengan namanya, perjanjian dibagi menjadi 2 (dua) macam yaitu perjanjian bernama (nominaat) dan perjanjian tidak bernama (innominaat). ${ }^{9}$ Nominaat atau perjanjian bernama adalah perjanjian khusus yang mempunyai nama sendiri yang sudah diatur dan diberi nama oleh pembentuk undang - undang berdasarkan kebutuhan hukum pada dinamika masyarakat. Perjanjian bernama ini berada pada buku ke-tiga KUH Perdata.

Innominaat atau perjanjian tidak bernama merupakan jenis perjanjianperjanjian yang tidak diatur dalam KUH Perdata tetapi terdapat di dalam masyarakat. Perjanjian tidak bernama ini lahir berdasarkan asas kebebasan berkontrak (freedom of contract). Pengertian asas kebebasan berkontrak ini tersirat pada pasal 1338 ayat

\footnotetext{
7 Jimly Asshiddiqie, Pokok-Pokok Hukum Tata Negara Indonesia Pasca Reformasi (Bhuana Ilmu Komputer 2008).[833].

8 W. Riawan Tjandra, Hukum Keuangan Negara (Grasindo 2006).[2].

9 Salim HS, Perkembangan Hukum Kontrak di Luar KUH Perdata (Raja Grafindo Persada 2006).[1].
} 
(1) KUH Perdata. Menurut Subekti, cara menyimpulkan asas kebebasan berkontrak ini adalah dengan jalan menekan pada perkataan "semua" yang dimuka perkataan “perjanjian". ${ }^{10}$ Meskipun asas ini memberikan kebebasan yang luas kepada para pihak untuk menentukan isi dan bentuk perjanjian akan tetapi harus tetap melihat batasanbatasan yang membatasi kebebasan berkontrak yakni, tidak boleh bertentangan dengan undang - undang, kesusilaan, dan ketertiban umum (pasal 1339 BW).

Menurut Black's Law Dictionary pengertian nominee adalah: ${ }^{11}$

1. A person who proposed for an office, membership, award or like tittle, or status. An individual seeking nomination, election or appointment is a candidate. A candidate for election becomes a Nominee after being formally nominated.

2. A person designated to act in place of another usually in a very limited way

3. A party who holds bare legal title for the benefit of others or who receives and distributes funds for the benefit of others.

Pada perjanjian nominee dalam pengalihan hak atas tanah dan/atau bangunan terdapat macam-macam potensi penghindaran pajak yang timbul dari perjanjian tambahan/turunan dari perjanjian nominee tersebut. Perjanjian tambahan pada perjanjian nominee ini dibuat berdasarkan kesepakatan antara dua belah pihak baik beneficial owner maupun nominee dengan tujuan untuk memperkuat ikatan mereka dan meminimalisir wanprestasi. Adapun jenis pajak yang menjadi potensi untuk dihindari adalah:

1. Pajak Penghasilan atas Sewa Tanah dan/atau Bangunan

Umumnya, perjanjian nominee dalam pengalihan hak atas tanah dan/atau bangunan bermula dari perjanjian jual beli, yang kemudian ditambahkan dengan perjanjian sewa-menyewa dan/atau perjanjian utang-piutang. Pada perjanjian tambahan dalam bentuk sewa-menyewa, kedua belah pihak menentukan isi perjanjian serta isi tambahan (addendum) dalam perjanjian tersebut. Akan tetapi, klausula-klausula baku yang berupa jumlah biaya sewa, jangka waktu dan metode pembayaran yang

\footnotetext{
${ }^{10}$ Subekti, Aneka Perjanjian (Alumni 1982).[36].

${ }^{11}$ Bryan A. Garner, Black's Law Dictionary, 8th edition, (West St. Paul, 2004).[1076].
} 
tercantum dalam perjanjian tambahan ini tidak dilakukan dan dibayarkan.

Sehingga dapat disimpulkan bahwa sebenarnya tidak ada transaksi yang dilakukan oleh kedua belah pihak, karena perjanjian ini dibuat sedemikian rupa hanya untuk memperkuat pihak beneficial owner dalam meminimalisir wanprestasi yang mungkin dilakukan oleh pihak nominee. Atas perjanjian yang "pura-pura" ini negara dirugikan dengan penghindaran PPh atas Penghasilan Persewaan Tanah dan/atau Bangungan sebesar 10\% yang sudah tertuai dalam Pasal 4 (1) Peraturan Pemerintah Republik Indonesia Nomor 34 Tahun 2017 tentang Pajak Penghasilan atas Penghasilan Dari Persewaan Tanah dan/atau Bangunan.

2. Pajak Penghasilan atas Bunga Pinjaman dari Mekanisme Utang-Piutang Sama halnya dengan pajak penghasilan atas sewa-menyewa, tujuan diberlakukannya perjanjian tambahan yang berupa utang-piutang ini untuk memberikan perlindungan bagi beneficial owner agar dapat lebih mengikat nominee serta meminimalisir wanprestasi. Dalam perjanjian utang-piutang ini tidak mencantumkan jangka waktu pengembalian dan jumlah pokoknya karena hanya bertujuan untuk mengikatkan diri kedua belah pihak. Sehingga terdapat objek pajak penghasilan atas bunga pinjaman sebesar 15\% sesuai dengan Pasal 23 (1) Undang - Undang Nomor 38 Tahun 2007 tentang Perubahan Ke Empat Atas Undang - Undang Nomor 7 Tahun 1983 tentang Pajak Penghasilan.

Pada sistem perpajakan yang menggunakan mekanisme Self Assessment System Wajib Pajak diberikan kepercayaan untuk menghitung, memperhitungkan, membayar serta melaporkan sendiri besarnya pajak terutang dalam suatu masa dan/ atau tahun pajak. Contoh nyata pelaksanaan Self Assessment System adalah dengan adanya penyampaian Surat Pemberitahuan (SPT) yang memuat hal-hal terkait pokok-pokok objek maupun dasar perhitungan pajak dari Wajib Pajak. ${ }^{12}$

Tidak akan menjadi sebuah permasalahan jika pajak yang telah dibayar, dihitung, diperhitungkan, dan dilaporkan melalui SPT sudah sesuai dengan

\footnotetext{
${ }^{12}$ Nindi Achid Arifki, 'Penyelesaian Kerugian pada Pendapatan Negara melalui Pengungkapan Ketidakbenaran (Suatu Kajian Hukum Doktrinal dalam Sistem Perpajakan)'(2019) 1 Jurnal Suara Hukum.[98].
} 
ketentuan perpajakan. Akan menjadi permasalahan jika masih terdapat pajak yang kurang bayar atau pajak terutang yang merupakan bagian dari objek kerugian pada pendapatan negara. ${ }^{13}$

Selain untuk meminimalisir wanprestasi dan untuk mengikatkan para pihak, perjanjian tambahan ini juga mengamankan pengalihan hak tanah tersebut dari penyewa dengan keturunan si penyewa. Biasanya memuat ketentuan bahwa WNI Nominee akan menyewakan tanah dalam jangka panjang dan dapat diperpanjang secara otomatis. Karena perjanjian ini merupakan perjanjian tambahan yang bersifat pura-pura maka tidak ada transaksi yang terjadi diantara dua pihak tersebut, hanya sebatas memperkuat perjanjian nominee sebelumnya. Meski demikian, mekanisme ini terdapat potensi pajak yang tidak dibayarkan berupa $\mathrm{PPh}$ atas sewa sebesar $10 \%$ yang jumlah netto nya bergantung dari harga sewa dalam addendum perjanjian tambahan tersebut.

Sedangkan pada perjanjian utang piutang sebagai perjanjian tambahan dari perjanjian nominee, WNI akan menyatakan bahwa ia memiliki utang kepada WNA dalam jumlah dan jangka waktu tertentu. Umumnya skema ini dibuat tanpa klausul jangka waktu pinjaman serta tidak menyatakan jumlah bunga ataupun selisih jumlah pokok sekarang dan yang akan datang. Sama dengan perjanjian sewa menyewa sebelumnya, perjanjian ini pada dasarnya adalah perjanjian purapura sehingga tidak ada transaksi antara kedua belah pihak tersebut. Terdapat beban pajak objek PPh atas bunga pinjaman sebesar 15\%.Dalam perjanjian nominee dalam pengalihan hak atas tanah dan atau bangunan beban pajak yang terutang terletak pada nominee sebagai pemilik tanah secara de facto dan de jure. ${ }^{14}$ Akan tetapi pemilik manfaat sesungguhnya adalah beneficial owner itu sendiri, secara mendasar memungkinkan pemilik manfaat itu mengaburkan data perpajakan yang sebenarnya seperti harta ataupun penghasilan, sehingga dapat menimbulkan kerugian pada pendapatan negara karena kurangnya pajak yang seharusnya dibayarkan.

\footnotetext{
13 ibid.

${ }^{14}$ M.Taufiq Budiarto.[450].
} 
Pada Pasal 12 ayat (3) UU KUP menyebutkan bahwa jika otoritas perjapakan menemukan data, bukti, dan keterangan lainnya terkait ketidaksuaian pembayaran pajak, otoritas pajak dapat melakukan penetapan atas pajak yang kurang dibayar atau jumlah pajak yang terutang. ${ }^{15}$ Sebagai parameter, ketetapan ini akan menunjukkan utang pajak jika terdapat bukti atau data yang mengarah kepada tidak dilaksanakannya kewajiban pajak sesuai dengan ketentuan perpajakan.

Sehingga meskipun bersifat self assessment tetap dapat dilakukan penetapan pajak oleh otoritas berdasarkan data, bukti sesuai peraturan perundang-undangan di bidang perpajakan. Kerugian pada pendapatan negara dapat diartikan sebagai pajak yang kurang bayar yang secara nyata dapat dibuktikan. Atas pembayaran pajak yang kurang bayar tersebut dapat menjadi unsur objek kerugian pada pendapatan negara.

\section{Akibat Hukum Penghindaran Pajak Terhadap Skema Praktek Perjanjian Nominee Dalam Pengalihan Hak Atas Tanah Dan/Atau Bangunan}

Penghindaran pajak atau tax avoidance dapat diartikan sebagai upaya wajib pajak untuk mengurangi beban pajaknya dengan tidak melakukan tindak pidana yang berarti mengikuti aturan yang ada pada Undang-Undang di bidang perpajakan. Penghindaran pajak berciri fraus legis yakni kawasan abu abu antara pemenuhan pajak dan penggelapan pajak. Penghindaran pajak dengan tidak melanggar Undang - Undang dilakukan secara legal dengan tujuan untuk memaksimalkan pendapatan setelah pajak meskipun berlawanan dengan maksud dari pembuatan Undang- Undang.

Penghindaran pajak merupakan pengurangan pajak secara ekspilisit dengan kegiatan penghematan pajak yang sah di satu sisi sedangkan kegiatan perlindungan pajak akan lebih dekat ke sisi lainnya. ${ }^{16}$ Tax Avoidance menurut Lyons Susan M dalam buku Hukum Pajak Erly Suandy, yaitu:

"Tax Avoidance is a term used to describe the legal arrangements of tax fair's affairs so as to reduce his tax liability. Its often to pejorative overnotes, for example it is use to describe avoidance achieved by artificial arrangements

\footnotetext{
${ }^{15}$ Nindi Achid Arifki.[94].

${ }^{16}$ Hanlon M \& Heitzman S, 'A review of tax research' (2010) Vol.50 Journal of Accounting and Economics.[127].
} 
of personal or business affair to take advantage of loopholes, ambiguities, anomalies, or other deficiencies of tax law. Legislation designed to counter avoidance has become more commonplace and often involves highly complex provision". ${ }^{17}$

Sesuai dengan yang sudah penulis sampaikan sebelumnya, Perjanjian nominee adalah perjanjian antara WNI dan WNA yang menggunakan nama WNI, yang kemudian hak WNI tersebut diserahkan kepada WNA melalui surat kuasa untuk bebas melakukan apa saja yang berkaitan dengan perbuatan hukum terhadap tanah yang dimiliki, atau nama WNI sebagai nominee dipinjam dan digunakan oleh WNA sebagai beneficial owner untuk dicantumkan sebagai pemilik atas tanah dan/atau bangunan. Perjanjian nominee dalam pengalihan tanah pada hakekatnyta berisikan tentang pernyataan penyerahan penguasaan tanah dan/atau bangunan oleh WNI kepada WNA, oleh karenanya WNA itu dapat menunjuk kepada seseorang yang merupakan pihak ketiga baik orang pribadi WNI atau Badan yang mewakili kepentingan orang asing tersebut.

Dengan adanya pembatasan-pembatasan yang ditetapkan oleh Pemerintah sebagai mana tertuang dalam suatu ketentuang peraturan perundang - undangan menyebabkan individu tertentu mencari jalan keluar dengan melahirkan konsepkonsep baru, antara lain konsep nominee. ${ }^{18} \mathrm{Hal}$ ini menjadi salah satu alasan yang mendasari penggunaan konsep nominee dalam sistem hukum di Indonesia.

Kegiatan transaksi hukum yang menimbulkan pengalihan hak atas tanah dan/atau bangunan tersebut mempunyai mekanisme perjanjian tertentu beserta perjanjian tambahan untuk memperkuat posis tawar para pihak, yang dapat dikategorikan sebagai berikut: ${ }^{19}$

1. Mekanisme Jual Beli

2. Mekanisme Perjanjian Sewa Menyewa sebagai pelengkap dari Perjanjian nominee

3. Mekanisme Utang Piutang

\footnotetext{
${ }^{17}$ Erly Suandy, Hukum Pajak Edisi 6 (Salemba Empat, 2014).[6].

${ }^{18}$ Lucky Suryo Wicaksono, 'Kepastian Hukum Nominee Agreement Kepemilikan Saham Perseroan Terbatas' (2016), Vol 23, Jurnal Hukum IUS QUIA IUSTUM.[45].

${ }^{19}$ M. Taufiq Budiarto,Op.Cit.,[449].
} 
Pada perjanjian nominee terutama di bidang pengalihan tanah pada prakteknya dimungkinkan bagi beneficial owner yang merupakan warga negara asing untuk mempunyai tanah meskipun sudah dilarang dan tercantum dalam UUPA dengan cara melakukan kegiatan jual beli melalui nomine yakni Warga Negara Indonesia, maka secara yuridis normatif tidak menyalahi surat yang dibuat oleh Notaris atau PPAT.

Warga Negara Asing mempunyai skema tersendiri dalam melakukan peralihan hak milik atas tanah agar tidak tersangkut hukum, adapun sebagai berikut: ${ }^{20}$

a. Akta Jual Beli dilakukan dengan meminjam nama seorang Warga Negara Indonesia. Akta jual beli itu merupakan tindakan pura-pura seakan ada perpindahan kepemilikan atas tanah tersebut, karena nama nominee yang kebetulan warga negara Indonesia hanya dipinjam saja untuk dituliskan kedalam sertifikat, meskipun yang sebenarnya modal dasar pembelian tanah tersebut berasal dari beneficial owner.

b. Akta Pengakuan Hutang.

Perjanjian tambahan yang berbentuk akta pengakuah hutang diaman WNI yang dipinjam namanya memilki hutang yang belum terbayarkan kepada orang asing sebagai pemilik manfaat, karena modal awalnya milik orang asing.

c. Akta tersebut dilanjutkan dengan akta tentang hak penguasaan tanah yang diberikan WNI kepada WNA

Adapun skemanya sebagai berikut:

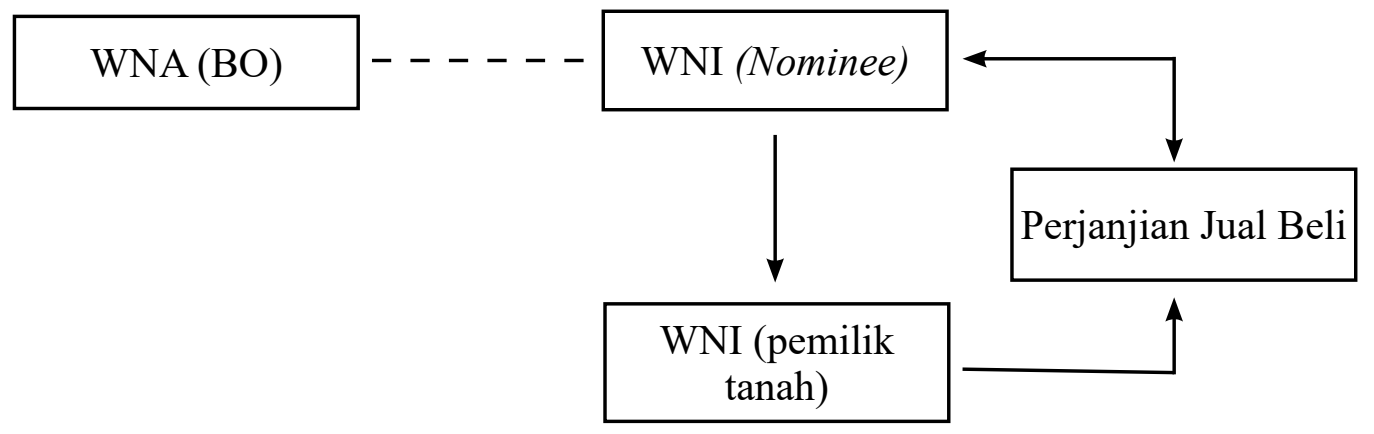

Gambar 1: Skema Perjanjian Nominee Jual Beli

${ }^{20}$ M Taufiq Budiarto,Op.Cit.,[450]. 
Skema diatas merupakan salah satu mekanisme perjanjian nominee yang sangat sering ditemukan, WNA sebagai pemilik manfaat (beneficial owner) meminta WNI sebagai wakilnya (nominee) untuk mengatasnamakan tanah yang akan dibeli. Kedua belah pihak baik WNAmaupun WNI nominee mempunyai kesamaan yang serupa dengan dengan konsep trust. Trust merupakan pemisahan kepemilikan antara kepemilikan legal (legal ownership) dan beneficial owner. Legal ownership dalam hal ini adalah WNI, akan menjadi trustee yang berfungsi sebagai pihak pengatur dan pengelola properti yang dimiliki oleh beneficial owner tersebut dan segala keuntungan menjadi milik beneficial owner. Adapun pada praktek jual beli tidak terdapat penghindaran pajak, penghindaran pajak terjadi pada perjanjain tambahan pada perjanjian jual beli, yakni perjanjian sewa menyewa dan perjanjian utang-piutang.

Sewa menyewa pada dasarnya adalah suatu perjanjian konsesuil, keabsahannya tercapai pada kesepakatan mengenai barang dan harga. KUHPerdata tidak menyebutkan secara khusus mengenai bentuk perjanjian sewa menyewa. Adapun unsur-unsur yang tercantum dalam perjanjian sewa menyewa adalah:

a. Adanya pihak yang menyewakan dan pihak yang menyewa

b. Adanya kesepakatan antara kedua belah pihak

c. Adanya objek sewa menyewa

d. Adanya kewajiban dari pihak yang menyewakan untuk menyerahkan kenikmatan kepada pihak penyewa atas suatu benda

e. Adanya kewajiban dari penyewa untuk menyerahkan uang sewa kepada pihak yang menyewakan

Perjanjian Sewa Menyewa merupakan addendum dari Perjanjian Nominee yang bertujuan untuk menguasai hak milik atas tanah yang dilakukan warga negara asing. Adapun skema perjanjiannya sebagai berikut:

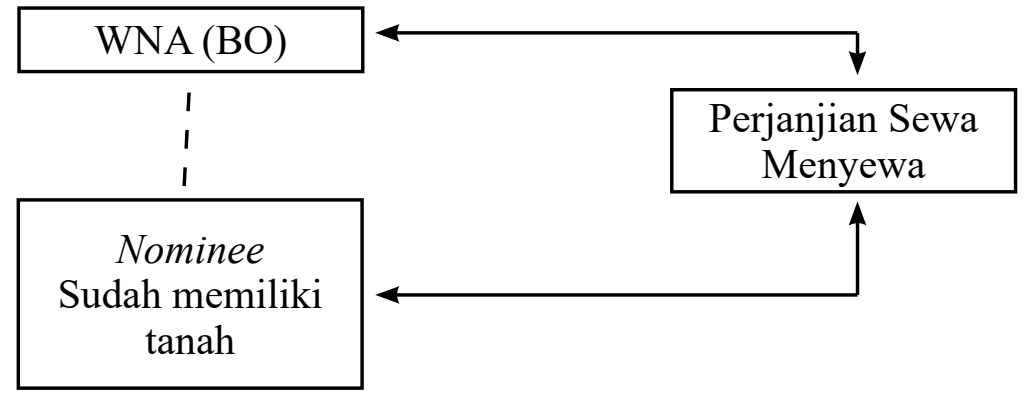

Gambar 2: Skema Perjanjian Tambahan Sewa Menyewa Pada Perjanjian Nominee 
Dalam perjanjian ini WNI (nominee) akan menyewakan tanah dalam jangka waktu yang tidak ditentukan sebagai mekanisme awal dan WNA selaku penyewa akan membayar harga sewa tanah secara wajar dengan kondisi harga pada waktu tersebut. Untuk memenuhi perjanjian sewa menyewa tersebut dibutuhkan akta otentik. Melalui akta sewa menyewa ini pihak penyewa dalam hal ini adalah beneficial owner (WNA) dan pihak yang menyewakan dalam hal ini adalah nominee (WNI) akan mencantumkan klausula-klausula baku pada perjanjian sewa menyewa ini, seperti; jangka waktu, harga sewa, metode pembayaran, serta hak dan kewajiban penyewa dan yang menyewakan.

Pada umumnya perjanjian turunan ini ditujukan untuk mengelabui Peraturan Pemerintah Nomor 103 Tahun 2015 tentang Pemilikan Rumah Tempat Tinggal atau Hunian oleh Orang Asing yang Berkedudukan di Indonesia. Dalam PP tersebut disebutkan bahwa:

"Rumah Tunggal yang diberikan di atas tanah Hak Pakai yang dapat dimiliki Orang Asing diberikan untuk jangka waktu 30 (tiga puluh) tahun, dan dapat diperpanjang untuk jangka waktu 20 (dua puluh) tahun. Dalam hal jangka waktu perpanjangan sebagaimana dimaksud berakhi, Hak Pakai dapat diperbaharui untuk jangka waktu 30 (tiga puluh) tahun".

Atas mekanisme ini akan terdapat potensi obyek PPh atas Penghasilan Persewaan Tanah dan/atau Bangunan sebesar 10\% sesuai dengan Pasal 4 Ayat(1)Peraturan Pemerintah RI Nomor 34 Tahun 2017 tentang Pajak Penghasilan Atas Penghasilan Dari Persewaan Tanah Dan/Atau Bangunan. Namun dengan adanya akta kegiatan sewa menyewa tersebut seorang warga negara asing mampu memanfaatkan tanah yang telah dikuasainya dengan tempo yang lebih lama dari PP No.103 Tahun 2015 dan bisa terus diperpanjang hingga lebih dari 100 (seratus) tahun, dan bisa diteruskan oleh ahli warisnya. ${ }^{21}$

Pada skema utang piutang terdapat perjanjian utang piutang yang menyebutkan bahwa WNI sebagai nominee memiliki utang yang belum terbayar kepada WNA sebagai beneficial owner dengan jumlah tertentu dan waktu tertentu. Adapun skemanya sebagai berikut:

${ }^{21}$ ibid. 


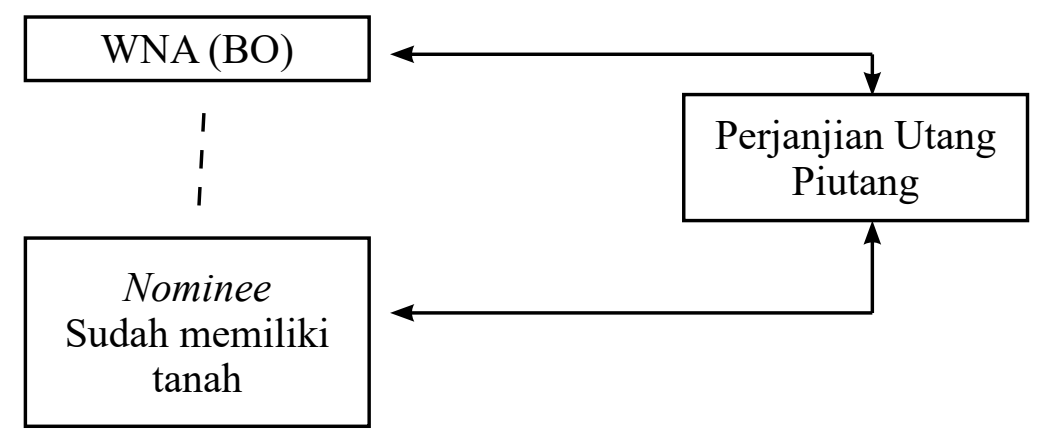

Gambar 3: Skema Perjanjian Tambahan Utang Piutang Pada Perjanjian Nominee

Tujuan diadakannya perjanjian utang-piutang ini adalah untuk mengikat WNI nominee dengan WNA yang isinya meliputi jumlah harga tanah dan dijadikan jaminan utang. Karena penduduk Indonesia yang berstatus Warga Negara Asing tidak dapat membelinya langsung sehingga menggunakan nama nominee yang berkewarganegaraan Indonesia tersebut. Dapat disimpulkan bahwa perjanjian utangpiutang ini merupakan perjanjian turunan dari perjanjian nominee sebelumnya.

Namun skema ini diuraikan tanpa menyatakan jangka waktu pengembalian dan tidak menyebutkan pokok bunga atau selisih jumlah bunga sekarang dengan jumlah uang kedepannya. ${ }^{22}$ Pada dasarnya tercantum objek pajak penghasilan atas bunga pinjaman sebesar 15\% sesuai yang tercantum pada Pasal 23 Ayat (1) UndangUndang Nomor 38 Tahun 2008 tentang Perubahan Ke Empat Atas Undang-Undang Nomor 7 Tahun 1983 tentang Pajak Penghasilan. Dalam Undang - Undang Pajak Penghasilan Pasal 23 menyebutkan:

"Atas penghasilan tersebut dibawah ini dengan nama dan dalam bentuk apapun yang dibayarkan, disediakan untuk dibayarkan, atau jatuh tempo pembayarannya oleh badan pemerintah, subjek pajak badan dalam negeri, penyelenggara kegiatan, bentuk usaha tetap, atau perwakilan perusahaan luar negeri lainnya kepada wajib pajak dalam negeri atau bentuk usaha tetap, dipotong pajak oleh pihak yang wajib membayarkan..."

Perjanjian utang-piutang ini hanyalah suatu cara untuk mengikatkan diri antara nominee dengan beneficial owner. Oleh karenanya akan sangat mungkin para pihak untuk tidak melaksanakan perjanjian tersebut dengan yang sebenar-

${ }^{22}$ ibid. [452]. 
benarnya, sehingga perjanjian utang-piutang ini tidak akan menghasilkan sebuah pembayaran. Maka obyek PPh atas bunga pinjaman sebesar 15\% tersebut tidak terbayarkan. Untuk mencegah penghindaran pajak melalui skema ini, dapat menggunakan doktrin substance over form dimana otoritas pajak dapat menghitung penghasilan bunga (deemed interest) atas pemberian pinjaman tanpa bunga tersebut tanpa objek pajak. ${ }^{23}$

Dalam Perjanjian Nominee, beban pajak yang terutang oleh beneficial owner dari harta yang disamarkan dapat dielakkan. Harta yang disamarkan dapat dikategorikan sebagai pengungkapan ketidakbenaran SPT. Dalam muatan isi UU KUP, pengungkapan ketidakbenaran SPT dibagi menjadi 2 (dua) yakni:

1. Pengungkapan ketidakbenaran SPT;

2. Pengungkapan ketidakbenaran Perbuatan;

Profesor Ronan Palan dalam bukunya yang berjudul "How Globalization Really .Works" mengatakan bahwa suatu transaksi dapat dikatakan sebagai tax avoidance apabila melakukan salah satu tindakan berikut: ${ }^{24}$

1. Wajib Pajak (WP) berusaha untuk membayar pajak lebih sedikit dari yang seharusnya terutang dengan memanfaatkan kewajaran intrepretasi hukum pajak;

2. Wajib Pajak (WP) berusaha agar pajak dikenakan atas keuntungan yang di sampaikan, bukan atas keuntungan yang sebenarnya diperoleh;

3. Wajib Pajak mengusahakan penundaan pembayaran pajak.

Oleh karenanya perjanjian nominee dalam dalam pengalihan hak atas tanah dan/atau bangunan merupakan penghindaran pajak. Pengungkapan ketidakbenaran SPT dilakukan oleh Wajib Pajak sebelum disampaikannya Surat Pemberitahuan Hasil Pemeriksaan kepada Wajib Pajak dikenakan sanksi sebesar 50\% dari

\footnotetext{
${ }^{23}$ Dyah Ayu Ambarwati, 'Pengelakan Pajak melalui Perjanjian Nominee dalam Bisnis Properti'(2019)< http.//news.ddtc.co.id/pengelakan-pajak-melalui-perjanjian-nominee-dalam-bisnis-properti-12499>, accessed 22 May 2019.

${ }^{24}$ Estu Suryowati 'Apa Perbedaan Praktik Penghindaran Pajak dan Penggelapan Pajak'(2016)<https://money.kompas.com/read/2016/04/14/083000826/Apa.Perbedaan.Praktik.Penghindaran.Pajak.dan.Penggelapan.Pajak.?page=all>, accessed 18 May 2019.
} 
jumlah pajak kurang bayar. Berbeda dengan pengungkapan ketidakbenaran atas perbuatan lebih mengarah terhadap adanya indikasi tindak pidana pajak. Pada substansi UU KUP, pengungkapan ketidakbenaran perbuatan dibagi dalam 2 bentuk dan batasan waktu, yaitu: ${ }^{25}$

1. Pada saat di indikasi melakukan tindak pidana, tetapi belum dimulainya tindakan penyidikan atau surat pemberitahuan dimulainya penyidikan belum disampaikan. Atas pengungkapan ketidakbenaran perbuatan ini dikenakan sanksi sebesar 150\% dari pajak yang kurang bayar;

2. Pada saat dilakukan penyidikan tetapi berkas perkara belum dilimpahkan kepada pengadilan, atas hal ini wajib pajak dikenakan sanksi denda sebesar $400 \%$ dari jumlah pajak yang kurang bayar.

Keberadaan Perjanjian Nominee telah mencederai prinsip keadilan dalam sistem pajak sekaligus menggerus basis penerimaan pajak, baik untuk Pajak Daerah maupun Pajak Pusat khususnya Pajak Penghasilan (PPh). Karena beban pajak atas penghasilan yang diperoleh beneficial owner dari harta yang disamarkan tersebut dapat dielakkan.

\section{Kesimpulan}

Perjanjian nominee dalam pengalihan hak atas tanah dan/atau bangunan pada dasarnya membutuhkan perjanjian tambahan untuk memperkuat ikatan antara nominee dan beneficial owner dalam hal ini antara WNI dan WNA untuk mengurangi sengketa dan resiko wanprestasi. Adapun skemanya merupakan praktek Jual Beli yang ditambahkan dengan praktek perjanjian sewa menyewa, dan praktek perjanjian utang piutang. Pada praktek jual beli tidak terdapat penghindaran pajak, penghindaran pajak terjadi pada perjanjain tambahan pada perjanjian jual beli, yakni:

Sewa Menyewa, Dalam praktek ini WNA dan WNI memiliki keuntungan dalam hal penguasaan ekonomi, bedanya WNA dapat memiliki jangka waktu yang lebih panjang serta memiliki kepastian hukum. Berdasarkan Peraturan Pemerintah

${ }^{25}$ Nindi Achid Arifki, Op.Cit.[99]. 
Nomor 103 Tahun 2015 dimungkinkan untuk melakukan praktek ini dengan jangka waktu tertentu. Adapun skema praktek ini dapat menimbulkan kerugian pendapatan negara dikarenan melakukan penghindaran Pajak Sewa Menyewa. Karena pada dasarnya perjanjian ini merupakan perjanjian tambahan maka sangat mungkin untuk tidak dilakukan sesuai dengan kesepakatan awal.

Hutang Piutang, Pada praktek ini WNA memiliki keuntungan penguasaan ekonomi dan juga kepastian hukum, sedangkan wni hanya memiliki keuntungkan ekonomi. Hutang piutang tercantum dan dapat dikaitkan dengan Undang - Undang Nomor 38 Tahun 2008 tentang Pajak Penghasilan. Adapun potensi kerugian pendapatan negara berupa Pajak Penghasilan $(\mathrm{PPh})$ atas bunga pinjaman sebesar $15 \%$. Akan sangat mungkin para pihak untuk tidak melaksanakan perjanjian tersebut dengan yang sebenar-benarnya, sehingga perjanjian utang-piutang ini tidak akan menghasilkan sebuah pembayaran. Maka obyek PPh atas bunga pinjaman sebesar $15 \%$ tersebut tidak terbayarkan.

Keduaskematersebutdapatdikategorikansebagaipengungkapanketidakbenaran SPT yang dilakukan oleh Wajib Pajak. Pengungkapan ketidakbenaran SPT sebelum disampaikan Surat Pemberitauan Hasil Pemeriksaan dikenakan sanksi sebesar 50\% dari pajak kurang bayar. Lain halnya dengan pengungkapan ketidakbenaran atas perbuatan yang menjurus terhadap indikasi tindak pidana pajak, jika surat pemberitahuan dimulainya penyidikan belum disampaikan dikenakan sanksi sebesar $150 \%$ dari pajak yang kurang bayar. Apabila pada saat dilakukan penyidikan namun berkas perkara belum dilimpahkan kepada pengadilan, maka wajib pajak dikenakan sanksi denda sebesar 400\% dari jumlah pajak yang kurang bayar.

\section{Daftar Bacaan}

\section{Buku}

Asshiddiqie, J., Pokok-Pokok Hukum Tata Negara Indonesia Pasca Reformasi (Bhuana Ilmu Komputer 2008).

Garner, B.A., Black's Law Dictionary, 8th edition (West, St. Paul 2004).

Harsono, B., Hukum Agraria Indonesia (Djambatan 2003). 
HS, Salim, Perkembangan Hukum Kontrak di Luar KUH Perdata (Raja Grafindo Persada 2006).

Marzuki, P.M., Penelitian Hukum Edisi Revisi (Kencana Prenada Media Group 2011).

Muhammad, A., Hukum Perjanjian (Citra Aditya Bakti Bandung 2000).

Suandy, E., Hukum Pajak, Edisi 6 (Salemba Empat 2014).

Subekti., Aneka Perjanjian (Alumni 1982).

Tjandra, W.R., Hukum Keuangan Negara (Grasindo 2006).

\section{Jurnal}

Arifki, N.A, 'Penyelesaian Kerugian pada Pendapatan Negara melalui Pengungkapan Ketidakbenaran (Suatu Kajian Hukum Doktrinal dalam Sistem Perpajakan)' (2018) 1 Jurnal Suara Hukum.

Budiarto, M.T., 'Sudut Pandang Perpajakan Atas Pengalihan Hak Tanah dan Bangunan dengan Mekanisme Perjanjian Nominee' (2018) Simposium Keuangan Negara.

M, H. \& S, H. 'A review of tax research' (2010) 50 Journal of Accounting and Economics.

Wicaksono, L.S., 'Kepastian Hukum Nominee Agreement Kepemilikan Saham Perseroan Terbatas' (2016) 23 Jurnal Hukum IUS QUIA IUSTUM.

\section{Internet}

Dyah Ayu Ambarwati, 'Pengelakan Pajak melalui Perjanjian Nominee dalam Bisnis Properti' (2019)<http.//news.ddtc.co.id/pengelakan-pajak-melaluiperjanjian-nominee-dalam-bisnis-properti-12499>, accessed 22 May 2019.

Estu Suryowati 'Apa Perbedaan Praktik Penghindaran Pajak dan Penggelapan Pajak'(2016)<https://money.kompas.com/read/2016/04/14/083000826/Apa. Perbedaan.Praktik.Penghindaran.Pajak.dan.Penggelapan.Pajak.?page=all $>$, accessed 18 May 2019.

HOW TO CITE: Zulfikar Muhammad Rafif, 'Penghindaran Pajak Pada Potensi Pajak Perjanjian Nominee Dalam Pengalihan Hak Atas Tanah Dan/Atau Bangunan’ (2019) Vol. 2 No. 6 Jurist-Diction. 